\title{
The Consequences of Political Identity for a Democratic System
}

\author{
Author: \\ Omen Sahabi, Ilya Nacho
}

\begin{abstract}
In today's political climate, there appears to be a greater focus on what would be good for people who belong to a particular gender, race, religion or sexual orientation. As a result of this, what would benefit people in general no longer has the same level of importance. An Obsession, It wouldn't be accurate to say that this is something that relates to people on both sides of the political spectrum, though. This is something that someone is more likely to be on board with if they are on the left. However, as the horseshoe theory points out; the further someone goes on either side of the spectrum, the closer their views will be. When this takes places, what someone on the far-left says might sound different to what someone on the farright comes out with, but that will be about as far as it will go. In Group Preference, One way of looking at the lefts obsession with identity politics would be to say that this is a form of tribalism. There is then no reason for someone from one group to assimilate with the members of another group. Also, by putting everyone into different groups, it makes it a lot harder for people to put their differences aside. In order for this to happen, people need to focus on what they have in common and not on what separates them from others. Two Groups, When someone has bought into this way of looking at the world, there will be people who oppress others and then there will be the people who are oppressed by others. This is something that is completely black and white. The biggest oppressors are often said to be white men, and this means that just about everything one else is kept down by these people. White women, on the other hand, are also seen as being oppressed, but they are still seen as having it easier than women who are not white. Taken To the Extreme Consequently, there are a number of people who believe that all the problems in the world would disappear is white men were removed from the planet. Ironically, this approach has a lot in common with how those on the far-right think- especially white supremacists.
\end{abstract}

Keyword: Political Identities; Polarization Society; Pop Culture; Democracy; Idelogy;

\section{Introduction}

For a little while now, there has been something called 'identity politics,' and one way of looking at this would be to say that this is a way of viewing the world. Everyone is seen as belonging to a particular gender, race, religion or sexual orientation. What this means is that it is not important what would benefit people in general; what matters is looking after a particular group. Therefore, people are not seen as individuals; they are seen as being part of a group that is either oppressed or part of a group that oppresses others.

Two Options, Once someone believes that they belong to a certain group, it can cause them to go one of two ways. Either they will believe that they are being held back, or they will 
believe that they are holding other people back. The former can then feel angry and full of rage, and the latter can end up feeling guilty and ashamed. One person will see themselves as a victim and the other will see themselves as a perpetrator.

Divide and Conquer, Instead of bringing people together, so that they can make the world a better place; this is something that just divides people. The energy that could be used to transform the planet is being wasted. As a result of this, identity politics can be seen as a great way to distract people and to make them believe that they have very little in common. Yet, if someone is told to focus on what they don't have in common with people who belong to another group, this is to be expected.

An Ulterior Motive, It could be said that there are certain people in this planet who want people to fight amongst themselves. What this does is allow these people to maintain control and to stop their fellow humans being from experiencing heaven on earth. However, while it would be easy to believe that these kinds of people have all the power that would overlook the part that people play in keeping their power structure alive. With that said, why would someone buy into identity politics?

One Thing, It has been said that human beings have an in-group preference, and this causes people to identify with people who look like them or who have a similar approach to life. This can be seen as something that relates to a human beings primal nature - something that happens without the need for someone to use their brain. There are likely to be plenty of people who gravitate towards a group because of this, and this could show that they have an aversion to thinking. What is going on for someone at an emotional level is also going to play a part here.

The Oppressed, If someone was to identity with a group that is said to be 'oppressed' by another group, there is the chance that they are not an empowered human being. Their early years may have been a time when they were victimised by others, and this could relate to what their parent/s did. Being told that they are victims is then going to match up with how they see themselves already. And through seeing themselves in this way, they could have a sense of entitlement, which will make them believe that they deserve to be given special treatment and resources. 
The Oppressor, On the other hand, if someone was to identify with a group that is said to 'oppress' others, they could also be a disempowered human being. The beginning of their life might have also been a time when they were treated badly. Thus, as they already feel guilty and ashamed of who they are, there will be no reason for them to push back against the people who abuse them for belonging to a particular group. This will be what feels comfortable, and the abuse that they receive from others can be no different to how they treat themselves.

An Escape, What someone like this can then do is end up abusing people who are said to belong to a group that oppresses others, with this being a way for then to feel better about themselves. They can believe that they are paying back the debt that they owe to the groups that they are oppressing. Someone like this is going to lack a strong sense of self and they will also be a self-hating human being. One can make out that they are virtuous for doing this, even though they are only behaving in this manner to manage their own pain.

A Lack of Empathy, Yet, regardless of whether one sees themselves as belonging to a group that is oppressed or oppresses others, they are going to find it hard to connect to truly others. When they see someone, they will either be put into one box or they will be out into another. This is going to stop them from being able to see that they are an individual; an individual that has their own needs and feelings. Not only this, the reality is that this person is going to have had moments in their life that were good and moments that were not - the group that they supposedly belong to is going to be irrelevant.

Mental Laziness, Being this way has a lot in common with someone who has disconnected from their own issues, so they end up seeing their issues in other people - they are going to be projecting their reality onto everyone else. Ultimately, identity politics stops someone from living in the present moment and causes them to be stuck in their head. After someone's mind has been infiltrated by this way of viewing the world - and this is something that can probably happen in a few days or less - they won't need to engage their brain. They will have a ready-made way of looking at the world and an answer as to why the world is the way it is. 


\section{Discussion}

\section{A. Identity - Religious, Ethnic, Linguistic?}

This past Sunday, my husband Teo and I attended the 5th annual Atlanta Arab Festival. Sponsored by the Alif Institute and the Arab American Women's Society of Georgia, the festival afforded attendees a wonderful mélange of Arabic food from Morocco, Syria, Israel, Palestine, and Lebanon as well as Arabic music, arts and crafts, shopping at a charming souk, and several exhibitions focusing on past and present Arab intellectual achievements and Arab history in the United States. After having a fabulous lunch of Moroccan and Palestinian fare, Teo and I wondered around the festival talking to the many festival goers and organizers. We spent some time at the dessert booth relishing in the decadent array of Arabic sweets and talking to Helen and Widad-members of the Arab American Women's Society of Georgia which was responsible for the fabulous assortment of popular Arabic sweets. I was particularly taken with the homemade basbousa, a semolina cake soaked in sweet syrup and kissed with a delicate essence of rose water.

You may be wondering why I am writing about this festival and what it has to do with religion? Well bear with me and let's enjoy the rest of the tour before getting to the serious stuff. After dessert (I bought some basbousa to go), Teo and I went to see the exhibition located inside of the Alif Institute. Upon entering the exhibition, we immediately encountered wall posters listing prominent American-Arabs such as Salma Hayek, Ralph Nadar, Tony Shalhoub, George Mitchell, John Sununu, Spencer Abraham, Helen Thomas, Marlo Thomas, Bobby Rahal, Paul Anka, Paula Abdul, and Shakira. The exhibition also provided a historical tour of Arab achievements in science, math, and technology, along with examples of the fine Arabic artwork from various countries. Beautiful glassware from Iraq, Eastern Orthodox Christian Icons from Lebanon, and inlaid furniture from Syria were prominently on display. One of the most poignant exhibits honored the four generations of the Najjar family who had proudly served in the U.S. military. Aside from the exhibits, the Alif Institute provided a range of learning activities for children and adults. 
During the tour of the exhibit, as I spoke to many of the attendees, it occurred to me that in celebrating Arab history and culture, this festival had managed to transcend the religious conflict that so often grasps our attention on the nightly news. I was surrounded by Muslim, Christian, and secular Arabs who had put aside their religious differences to celebrate their cultural/ethnic identity. Unfortunately, Americans are often unaware of the religious and ethnic diversity that exists in the Arab world but fortunately, the Alif Institute did an amazing job organizing and presenting this diversity to festival goers, Arab and non-Arab alike. According to the festival program, the Alif Institute determines Arab identity according to spoken languagenot ethnicity.

\footnotetext{
"Arabs are diverse peoples who live in 22 nations: Algeria, Bahrain, Comoros, Djibouti, Egypt, Iraq, Kuwait, Lebanon, Libya, Mauritania, Morocco,, Oman, Palestine, Qatar, Saudi Arabia, Somalia, Sudan, Syria, Tunisia, United Arab Emirates, and Yemen. The word "Arab" embraces more than 300 million multiethnic and multiracial Arabic-speaking peoples living in these countries. In addition to language, Arabs are unified by cultural and historical roots traceable to Abraham and Shem, the eldest of Noah's three sons, as well as the great Semitic migrations originating from the Arabian Peninsula that led to the rise of the Assyrians, Arameans, and Canaanites."
}

Of course, Arab identity is much more complicated and cannot simply be defined by a common language. Arabs almost always hold multiple identities at once such as: Syrian, Israeli, Palestinian, Egyptian, Lebanese, Muslim, Christian, Druze, Shia, Sunni, Catholic, Melkite Catholic, Coptic, Jewish, and secular Arab. Collective identity can be accessed not only through language but via religion, stories, history, tradition, politics, ideology, commemoration of events, or a simple celebration of one identifying factor which temporarily overrides religious, ideological, or political differences. The Atlanta Arab Festival drew Christian, Muslim, and secular Arabs together to celebrate the rich tapestry of Arab identity and achievements. I applaud their efforts and look forward to attending next year's event.

This brings me to the questions of the day: As the United States is most probably the most ethnically, racially, religiously, and linguistically diverse country in the world; what factors 
form our cohesive identity? Or-is the political and religious divisiveness so prominent in America today emblematic of a lack of unifying factors?

\section{B. Cross Cultural Negotiations}

As our ability to reach into the furthest corners of the world increases through technology and the world shrinks through "globalization", we have been lulled into believing that culture is no longer as important a differentiator as it once was. Culture has, in fact, become a defining component in the success of the entrepreneur in understanding and being able to effectively react to the variations in negotiation styles that are influenced by the region and/or heritage of those with whom we are doing business.

Culture is defined in the dictionary as "the totality of socially transmitted behaviour patterns, arts, beliefs, institutions, and all other products of human work and thought." In simpler terms, it is who we are as a result of where and how we were raised. How we think, our reactions, our approach to a business relationship, our values can be reasonably predicted by understanding our background. The global negotiator must be ready to be a chameleon during a cross-cultural encounter to effectively close a deal.

The diversity of cultures spans into how information is processed and therefore how decisions are made. Does the culture encourage critical thinking and an approach that requires multiple different data points that are considered, prior to making a decision; or is it focused more on accepting tried and true methods, and external factors which would suggest that riskier approaches are discounted? If you choose to focus on a creative approach to your value proposition and you are negotiating in a country that prefers the latter, you will not be successful with your proposal.

Theatrics such as banging the table, yelling and stomping out of a negotiation might take an unseasoned North American negotiator by surprise, but in many cultures this is an accepted, and expected, method of negotiating. It is meant to intimidate and obtain concessions, but it is not meant personally in any way - it is part of the game. As a negotiator in such a situation you have two choices - you can either respond in kind, or you can be patient and wait them out. Remember, that although in our culture, collaboration and "win-win" are often touted as the 
ultimate approach, in some cultures compromise is considered a sign of weakness and is viewed with suspicion.

A seasoned negotiator will often try to manage a negotiation through an effective and fluent understanding and use of body language. This is a potential minefield when entering cross-cultural negotiations. In some countries they may negotiate at a closer distance than North Americans are comfortable with, and in others it may be further away. Eye contact is very much expected in the Western manner of negotiating although in some cultures it would be seen as an insult!

A woman negotiating in a different cultural milieu must be doubly cautious. In some countries it is inappropriate for a man and a woman, even in a business environment, to shake hands or touch in any way. As such, when confronted with unfamiliar terrain, a woman should always wait for the man to extend his hand. Furthermore, dress and body language of a female negotiator can have a huge impact on the success of the encounter.

\section{Politics of Popular Culture}

One cannot live on a myth in the present; the tradition is being constantly transformed; old is giving way to new in ways more than one. The new changes, or the crossover of trends and fashions, may be generating a feeling of existential urgency; the sublime seems to be melding with the trivial and the creative with the conventional. A sort of re-orientation is goingon so rapidly that the classical concepts of culture appear outdated.

It is also a fact that the greatest number of new ideas in contemporary art, literature and culture have been coming out from the West. Western artists and cultural leaders have been extending the concept of what constitutes contemporary art. It is important to take note of a convergence of new attitudes, especially as there has been a marked shift from the idealist to the materialist view.

The fabric of popular culture, now a celebratory, is interwoven with changes in the world of media, along side too much Soap Operas, MTV music, McDonald fast food, sexist jokes, designer-label jeans and aerobic sports-wear--all with a view to maintaining 'standards'. The so-called 'cultural industries' have been denigrated as tools of the hegemonic classes to 
impose a passive subservience on the majority of people, be it Europe, America, Asia or Africa. They manipulate the multi layered site of contemporary consumerist culture as well as the emerging hybridization of cultural identity.

A scrutiny of the 'popular', its texts and practices, should help us in negotiating the profound shifts in culture studies as also in relating post-modernist orthodoxy to the post-Cold War developments (in the erstwhile Soviet bloc, and/or East European countries), postapartheid developments (in South Africa and elsewhere on the African continent), post-colonial developments (in Asian and African countries), and more recently, post-Sept 11, 2001 developments (in South/South-east/West Asia, middle East, USA, and Europe).

The politics of popular culture, howsoever post-modernist or post-colonial, is essentially the politics of the ways in which we see ourselves, just as the cultural, the social, and the economic are hardly easily distinguishable from each other. The relationship between popular culture and its two arms, commerce and profit, is highly problematic. Instead of passively consuming a product, users now actively absorb it and reworth it to construct their own meaning of self, of social identity, and group cohesion.

After the Sept 11 terrorist attack on American soil, there has been a greater American hegemonic political and economic presence in every country: TV programmes, newspapers and magazines have been replete with American style and vision. Gradually, the American domination here, there and everywhere, has resulted in a struggle by the subordinate and subaltern forces, even terrorist forces, to demolish it.

A slow ideological indoctrination (to sustain consumerist culture) of the masses, especially the expanding middle class by powerful interests, is going on. The middle class culture is frequently less affiliated to specific class, religion, race, country or politics, and unofficially also remains indifferent to 'national' questions, practicing a sort of 'transnational' solidarity, as far as consumerism is concerned. The American popular culture has given rise, not so much to economic exploitation as the capacity to be able to represent something, or someone, in a peculiar way: as symbolic power; as popular culture within the ambit of power. The media society - whatever its form, shape, size, or colour - articulates this power, perhaps 
selectively, in a contradictory fashion throwing open for others to decide with whom to associate or empathize.

It exposes the mechanisms of identity-creation, participates in identity politics, creates awareness of exclusion or inclusion, and constructs counter-narratives with new critical spaces and social practice. It acts as "central political agent" of the powerful. The politics of popular culture reveals the conditions under which relationships of power have been shaped in various parts of the world and apparently developed in an emancipating way as everyday culture, or high culture, where new things are emerging and creativity is thriving. In music, for example, since the mid-1990s, musicians have been more lucrative. Choreographers have developed a new sense of body movement and dance aesthesis. Computer evolution has already led to a 'net culture' which links various art forms. Literature is already rooted in this world today and trends in fashion industry are set by FTV models.

At times it may appear difficult to reconcile the various impressions, including the desire to break free of all constraints in art or destruction of its intrinsic significance. The inherent contradictions and heterogeneity of the 'melting pot' that popular culture seems to have turned into may not help us open the path to the human consciousness or even initiate an intellectual debate. But whom to blame when "art blends so seamlessly into the utilitarian"? To quote Hanno Rauterberg, "Art, after all, is not dead, it is in a state of self-induced paralysis."

We are marching into an indistinct future. We experience the effects of globalization in such fields as communication, the media, and the financial markets just as we are experiencing fragmentation of politics vis-à-vis widespread religious, casteist and ethnic conflict, secular nationalism, and regional fundamentalism. At the same time, we are witnessing impoverishment and economic marginalization of a large part of the society. Almost all accepted norms and values are being called into question, just as standardization and differentiation obtain at the same time. However, the struggle continues for coexistence of the glorious past and naked modernization almost everywhere. 


\section{Conclusion}

This is then similar to how someone can do a weekend course in something and then see themselves as an expert. What can be different is that someone can see themselves as being morally superior when they have given their mind over to identity politics. It has been said that thinking is one of the hardest things to do, with this being the reason why it is often avoided. The trouble is that if one blindly adheres to a certain viewpoint, they can end up doing more harm than good.

Prolific writer, author, and coach, Oliver JR Cooper, hails from England. His insightful commentary and analysis covers all aspects of human transformation, including love, partnership, self-love, and inner awareness. With over one thousand six hundred in-depth articles highlighting human psychology and behaviour, Oliver offers hope along with his sound advice.

With all the differences and potential issues in negotiating in other cultures, how does one ensure that fear of a misstep doesn't result in paralysis? Cultural research must become another element of the planning and preparation phase when faced with these kinds of issues. Books, such as "Kiss, Bow or Shake Hands" by Terri Morrison et al., or just browsing the web can provide important insight into the best approach in a given country. Talking to colleagues or other business professionals who have had experience in the region can be a valuable resource.

What appears more appropriate is the need to appreciate the emergence of a greater degree of interculturalism. The ruling politicians should respect ones right to be different and help create new cultural spaces for others to belong. They should help defuse, absorb and avoid those conflicts that result from the collision of world religions and cultures which are rigidly separated and social differences must be honoured and dogmatism must give way to dialogue. Our living together in a global civilization is not possible without some sort of global ethos on the part of our country's politicians. 


\section{References}

Aldyan, R. A., Warto, W., \& Marimin, M. (2019). " Ngalab Berkah" on the Tradition to Open Luwur the Sunan Kudus Tomb. International Journal of Multicultural and Multireligious Understanding, 6(4), 156-165.

Aliya, Z., \& Frauch, J. (2020, January 6). The Future of Multi-Cultural Societies. Retrieved from https://www.academia.edu/41716470/The_Future_of_Multi-Cultural_Societies

Sadad, A., \& Masduki, F. (2020). Cultural Conflict: The Process of Cultural Identity Change in The Civilization. International Journal of Education, Culture and Society (IJECS), 2(1), 12-17.

Arikan, G., \& Bloom, P. B. N. (2019). Democratic Norms and Religion. In Oxford Research Encyclopedia of Politics.

Back, L. (2017). New ethnicities and urban culture: Social identity and racism in the lives of young people. Routledge.

Berger, A. A. (2017). Agitpop: Political culture and communication theory. Routledge.

Beveridge, R., \& Koch, P. (2017). The post-political trap? Reflections on politics, agency and the city. Urban Studies, 54(1), 31-43.

Brabazon, T. (2016). Thinking popular culture: war, terrorism and writing. Routledge.

Carlin, R. E., \& Love, G. J. (2018). Political competition, partisanship and interpersonal trust in electoral democracies. British Journal of Political Science, 48(1), 115-139.

Cherniavsky, E. (2017). Neocitizenship: political culture after democracy. NYU Press.

Clark, T. N. (2018). The new political culture. Routledge.

Crouch, C. (2016). The march towards post-democracy, ten years on. The political quarterly, 87(1), 71-75.

Dean, J. (Ed.). (2018). Cultural studies and political theory. Cornell University Press.

De Groot, I. (2017). Mock elections in civic education: A space for critical democratic citizenship development. JSSE-Journal of Social Science Education.

Dewi, E. W., Drajati, N. A., \& Yunus, M. M. (2019). Exploring Intonations in Sesame Street's Puppet Shows: A Phonological Perspective. Issues in Language Studies, 8(2), 32-47.

Escobar, A. (2018). The making of social movements in Latin America: Identity, strategy, and democracy. Routledge.

Franklin, D. P., \& Baun, M. J. (2016). Political Culture and Constitutionalism: A Comparative Approach: A Comparative Approach. Routledge.

Fowler, R. B. (2018). Religion and politics in America: Faith, culture, and strategic choices. Routledge.

Guo, D., \& Hu, S. (2019). Identity Politics and Democratic Crisis in Western Europe. Chinese Political Science Review, 4(2), 255-275.

Habibi, H. (2016). PERAN KI DALANG BASARI (1950-2003) DALAM PERKEMBANGAN ISLAM DI GEGESIK CIREBON. Jurnal Tamaddun: Jurnal Sejarah dan Kebudayaan Islam, 1(2).

Habibi, H. (2018). Protecting National Identity Based On The Value Of Nation Local Wisdom. International Journal of Malay-Nusantara Studies, 1(2), 24-40.

Haynes, J. (Ed.). (2016). Religion, globalization and political culture in the Third World. Springer. 
Huddy, L., \& Bankert, A. (2017). Political partisanship as a social identity. In Oxford research encyclopedia of politics.

Lacey, J. (2017). Centripetal democracy: Democratic legitimacy and political identity in Belgium, Switzerland, and the European Union. Oxford University Press.

Lupu, N., \& Peisakhin, L. (2017). The legacy of political violence across generations. American Journal of Political Science, 61(4), 836-851.

Meléndez, C., \& Rovira Kaltwasser, C. (2019). Political identities: The missing link in the study of populism. Party Politics, 25(4), 520-533.

Risse-Kappen, T. (2016). Collective identity in a democratic community. Domestic Politics and Norm Diffusion in International Relations: Ideas do not float freely, 78.

Ross, A. (2016). No respect: Intellectuals and popular culture. Routledge.

Van der Meer, T. W. (2017). Political trust and the "crisis of democracy". In Oxford Research Encyclopedia of Politics.

Vegetti, F. (2019). The political nature of ideological polarization: The case of Hungary. The ANNALS of the American Academy of Political and Social Science, 681(1), 78-96.

Westwood, S., \& Peterson, E. (2019). Compound political identity: How partisan and racial identities overlap and reinforce. Available at SSRN 3417476. 